\title{
Role of Reactive Oxygen Species in the Neural and Hormonal Regulation of the PNMT Gene in PC12 Cells
}

\author{
James A. G. Crispo, ${ }^{1,2}$ Dominique R. Ansell, ${ }^{1,3}$ Gino Ubriaco, ${ }^{1,3}$ and T. C. Tai ${ }^{1,2,3,4}$ \\ ${ }^{1}$ Medical Sciences Division, Northern Ontario School of Medicine, Sudbury, ON, Canada P3E 2C6 \\ ${ }^{2}$ Department of Chemistry \& Biochemistry, Laurentian University, Sudbury, ON, Canada P3E 2C6 \\ ${ }^{3}$ Department of Biology, Laurentian University, Sudbury, ON, Canada P3E 2C6 \\ ${ }^{4}$ Biomolecular Sciences Programme, Laurentian University, Sudbury, Canada P3E 2C6 \\ Correspondence should be addressed to T. C. Tai, tc.tai@nosm.ca
}

Received 31 May 2011; Accepted 12 July 2011

Academic Editor: Luisa Minghetti

Copyright $\odot 2011$ James A. G. Crispo et al. This is an open access article distributed under the Creative Commons Attribution License, which permits unrestricted use, distribution, and reproduction in any medium, provided the original work is properly cited.

\begin{abstract}
The stress hormone, epinephrine, is produced predominantly by adrenal chromaffin cells and its biosynthesis is regulated by the enzyme phenylethanolamine N-methyltransferase (PNMT). Studies have demonstrated that PNMT may be regulated hormonally via the hypothalamic-pituitary-adrenal axis and neurally via the stimulation of the splanchnic nerve. Additionally, hypoxia has been shown to play a key role in the regulation of PNMT. The purpose of this study was to examine the impact of reactive oxygen species (ROS) produced by the hypoxia mimetic agent $\mathrm{CoCl}_{2}$, on the hormonal and neural stimulation of PNMT in an in vitro cell culture model, utilizing the rat pheochromocytoma (PC12) cell line. RT-PCR analyses show inductions of the PNMT intronretaining and intronless mRNA splice variants by $\mathrm{CoCl}_{2}$ (3.0- and 1.76-fold, respectively). Transient transfection assays of cells treated simultaneously with $\mathrm{CoCl}_{2}$ and the synthetic glucocorticoid, dexamethasone, show increased promoter activity (18.5-fold), while mRNA levels of both splice variants do not demonstrate synergistic effects. Similar results were observed when investigating the effects of $\mathrm{CoCl}_{2}$-induced ROS on the neural stimulation of PNMT via forskolin. Our findings demonstrate that $\mathrm{CoCl}_{2}$-induced ROS have synergistic effects on hormonal and neural activation of the PNMT promoter.
\end{abstract}

\section{Introduction}

Epinephrine is synthesized by the catecholamine biosynthetic enzyme phenylethanolamine $\mathrm{N}$-methyltransferase (PNMT, EC 2.1.1.28) [1]. PNMT is a critical determinant of epinephrine production in adrenal chromaffin cells during acute and chronic stress. Stress contributes to the pathophysiology of many diseases and epinephrine and glucocorticoids (cortisol and corticosterone) are the major stress hormones that initiate the biological responses permitting the organism to cope with adverse physiological, psychological, and environmental stress [2]. All catecholamine biosynthetic enzymes including PNMT are stress responsive; however, their responses are stressor-specific, dependent on stress intensity, duration, and number of repeated exposures $[3,4]$.
The PNMT gene has been shown to be both hormonally and neurally regulated through activation of the hypothalamic-pituitary-adrenal (HPA) axis and the sympathoadrenal (SA) system [5]. Both activation mechanisms exert transcriptional and post-transcriptional influences on the PNMT gene [6-8]. Hormonal activation of the PNMT gene is dependent on extremely high concentrations of glucocorticoids which induce transcriptional changes via glucocorticoid response elements (GREs) upstream of PNMT transcription initiation site [9]. The activation of PNMT through the sympatho-adrenal system can occur via the release of acetylcholine and PACAP from the splanchnic nerve [5]. Neurotransmitters such as acetylcholine, serotonin, and the peptide neurotransmitter PACAP have been shown to induce PNMT via the protein kinase A (PKA) and protein kinase $\mathrm{C}$ 
(PKC) pathways $[10,11]$. In addition, both acetylcholine and PACAP activate signaling cascades that regulate transcription factors expressed exclusively in adrenergic cells such as the early growth response transcription factor 1 (Egr-1) and promote PNMT transcription [12].

Previous studies have shown that hypoxia is a potent stressor involved in the regulation of PNMT [13]. Cells experiencing lowered $\mathrm{O}_{2}$ levels (hypoxia) undergo a variety of biological responses in order to adapt to these unfavorable conditions [14]. Hypoxia, or decreased oxygen concentration, activates a variety of complex pathways at both the cellular and organism level with the ultimate aim of reinstating oxygen homeostasis. Although physiological responses to hypoxia have been appreciated for a long time, the molecular processes activated within the cells are still under investigation. However, this area has been greatly advanced by the discovery of a class of transcription factors that respond to hypoxia, HIF (hypoxia inducible factors) [15]. The HIFs stimulate a variety of genes, including PNMT [16-19].

Hypoxic conditions can also give rise to the production of reactive oxygen species (ROS) as well as reactive nitrogen species (RNS). The production of ROS/RNS is referred to as oxidative stress, a condition in which the balance between production and disposal of ROS/RNS is altered [20]. Several studies report that exposing cells or tissues to hypoxia increases oxidative stress and that this increase is generated by the mitochondria [21]. The ROS and RNS that arise from hypoxic conditions can lead to fixed changes in signal transduction and gene expression, resulting in disease development and progression [22]. ROS/RNS function as specific signaling molecules to trigger the activation of specific transduction pathways and damage to cellular components. ROS/RNS mediate these effects through the activation of specific transcription factors to control the transcription of a range of target genes. Several studies demonstrate that the delivery of $\mathrm{CoCl}_{2}$ to cultured cells can mimic hypoxic responses, including the increased production of ROS $[22,23]$. Additionally, exposure of PC12 cells to hypoxia-mimicking concentrations of $\mathrm{CoCl}_{2}$ has been shown to upregulate the transcription of HIF $1 \alpha$ and cause mitochondrial DNA damage [24].

The purpose of this study is to understand the role of oxidative stress arising from a hypoxic environment, and its effect on the hormonal and neural stimulation of PNMT. The effects of oxidative stress on PNMT and thereby epinephrine have not previously been shown and will allow for a better understanding of the impact of oxidative stress on the transcriptional machinery involved in the regulation of the PNMT gene. This, in turn, will allow us to better understand how epinephrine production is controlled via PNMT and its role as a neuroendocrine regulator in various disease states. The present study shows that under mimetic hypoxic stress generated via $\mathrm{CoCl}_{2}, \mathrm{PC} 12$ cells elicit the production of ROS and promote PNMT gene transcription. Additionally, oxidative stress arising from the hypoxia mimetic agent $\mathrm{CoCl}_{2}$ further promotes the transcription of the PNMT gene when combined with hormonal as well as with neural stimulation.

\section{Materials and Methods}

2.1. Cell Culture. PC12 cells (from D. O'Connor, UCSD, San Diego, CA, USA) were cultured in DMEM supplemented with $5 \%$ equine serum, $5 \%$ bovine serum and gentamycin sulphate $(50 \mu \mathrm{g} / \mathrm{mL})$. All cells were maintained in a humidified incubator at $37^{\circ} \mathrm{C}$ in an atmosphere of $5 \% \mathrm{CO}_{2}-$ 95\% air and grown to $80-90 \%$ confluency before being passed or used in an experiment. Hypoxia was achieved by displacement of oxygen from $21 \%$ to $5 \%$ with nitrogen gas. Prior to experimentation, cells were transferred to DMEM containing charcoal-treated serum. For transfection studies, cells were plated in 24-well tissue culture plates at a density of $4-5 \times 10^{5}$ cells/well. For total RNA extraction, cells were grown in $100-\mathrm{mm}$ culture dishes to a density of $5 \times 10^{5}-1.8 \times 10^{6}$ cells per dish. Following seeding, cells were allowed to adhere to plates for $16-24 \mathrm{~h}$ prior to beginning experiments. Cells were then drug treated with $\mathrm{CoCl}_{2}(200 \mu \mathrm{M})$, dexamethasone $(1 \mu \mathrm{M})$, N-acetylL-cysteine ( $5 \mathrm{mM})$ (Sigma-Aldrich, St. Louis, MO, USA), forskolin $(10 \mu \mathrm{M})$ (LC Laboratories, Woburn, MA, USA) or the combination of each agonist with $\mathrm{CoCl}_{2}$ for times and at concentrations specified in the figure legends.

\subsection{Measurement of Intracellular ROS by Flow Cytometry.} Production of intracellular ROS was quantified using the $\mathrm{CM}-\mathrm{H}_{2}$ DCFDA method (Invitrogen, C6827). Following treatments, culture media was collected in $15 \mathrm{~mL}$ conical tubes. Cells were then scraped with $1 \mathrm{~mL}$ cold phosphatebuffered saline (PBS, pH 7.4) and added to the conical tubes, centrifuged at $1,000 \mathrm{rpm}\left(5 \mathrm{~min}, 4^{\circ} \mathrm{C}\right)$ and washed with cold PBS (pH 7.4). Cell pellets were resuspended in $1 \mathrm{~mL} 2.5 \mu \mathrm{M}$ detection reagent, transferred to $1.5 \mathrm{~mL}$ centrifuge tubes and incubated at $37^{\circ} \mathrm{C}$ for 30 mins. Cells were then pelleted, resuspended in $1 \mathrm{~mL}$ culture medium, and incubated at $37^{\circ} \mathrm{C}$ for $30 \mathrm{~min}$. Following incubation, cells were centrifuged at $2,400 \mathrm{rpm}\left(8 \mathrm{~min}, 4^{\circ} \mathrm{C}\right)$ and washed with PBS (pH 7.4). Cells were then resuspended in $1 \mathrm{~mL}$ PBS ( $\mathrm{pH}$ 7.4) and analyzed using a flow cytometer (BD Biosciences, FACS Canto II). In brief, cells were excited with $488 / 10 \mathrm{~nm}$, and their fluorescence emission was recorded in the $530 / 30 \mathrm{~nm}$ range. The amount of intracellular ROS within cell populations is directly proportional to their mean fluorescent emission. Fluorescent emission values from 10,000 independent events were used to compute a mean fluorescent value for each treatment group. Treatment groups were then compared to stained control cells to determine the relative fold change of intracellular ROS.

2.3. Measurement of Nitric Oxide. Extracellular nitric oxide levels were quantified using the Nitric Oxide Analyzer (model 280, Sievers Instruments, Boulder, Colorado) [25]. Following treatments, culture media was collected in $1.5 \mathrm{~mL}$ centrifuge tubes. In brief, $10 \mu \mathrm{L}$ of media from each treatment was injected into a high-sensitivity detector. This device uses the chemiluminescent method to determine media content of nitrite $\left(\mathrm{NO}_{2}{ }^{\bullet}\right)$ and nitrate $\left(\mathrm{NO}_{3}{ }^{\bullet}\right)$, the stable oxidation products of NO. The nitroso-compounds $\mathrm{NO}_{2}{ }^{\bullet}$ and $\mathrm{NO}_{3}{ }^{\circ}$ are reduced to $\mathrm{NO}$ by exposure to vanadium 
chloride which is then determined from the gas-phase chemiluminescent reaction between $\mathrm{NO}$ and ozone. Emission from electronically excited nitrogen dioxide is in the red and near red infrared region of the spectrum and is detected by a thermoelectrically cooled, red-sensitive photomultiplier tube. A calibration curve using sodium nitrate standards was used to calculate concentrations for the samples.

2.4. RT-PCR. PC12 cells $\left(1.6 \times 10^{6}\right.$ cells $\left./ \mathrm{mL}\right)$ were seeded into 60-mm culture dishes in modified DMEM, and treated as previously described. Cells were harvested and lysed in $500 \mu \mathrm{L}$ Tri-Reagent (Sigma Aldrich Canada Ltd) and total RNA isolated per manufacturer's protocol. Total RNA pellets were resuspended in diethylpyrocarbonate-treated nuclease-free water and concentrations determined using spectrophotometric measurements of absorbance at $260 \mathrm{~nm}$ (NanoDrop; Nanodrop Technologies, Wilmington, DE).

$2 \mu \mathrm{g}$ of total RNA was treated with DNase I (Sigma Aldrich Ltd.) following manufacturer's protocol, and cDNA subsequently synthesized using $100 \mathrm{U}$ Revert Aid Moloney Murine Leukemia Virus reverse transcriptase enzyme as per manufacturer's protocol (Fermentas, Burlington, ON, Canada). PCR was performed in $25 \mu \mathrm{L}$ reaction volumes containing $78 \mathrm{ng}$ of cDNA, using $50 \mathrm{U}$ GoTaq Flexi DNA polymerase (Promega) containing $200 \mu \mathrm{M}$ of dNTPs, $1.5 \mathrm{mM}$ $\mathrm{MgCl}_{2}$, and $25 \mathrm{ng}$ of forward and reverse primer sequences specific for the following genes: PNMT and glyceraldehyde 3-phosphate dehydrogenase (GAPDH) (Table 1).

PCR products $(10 \mu \mathrm{L})$ were electrophoresed on a $1.5 \%$ agarose gel in $40 \mathrm{mM}$ Tris-acetate and $2 \mathrm{mM}$ EDTA buffer ( $\mathrm{pH} 8$ ), stained with ethidium bromide, documented using the Chemidoc XRS (Biorad) imaging system and densitometric analysis performed using the Quantity One software (Biorad).

2.5. Plasmids. The wild-type PNMT promoter-luciferase reporter gene construct pGL3RP893 was generated as previously described $[7,26,27]$. Competent $\mathrm{E}$. coli cells were transformed with plasmid DNA to generate the PNMT promoter-luciferase reporter gene construct, and DNA plasmids were subsequently purified using the Invitrogen PureLink HiPure Plasmid DNA purification kit (Invitrogen Invitrogen Life Technologies Corp. Burlington, ON, Canada).

2.6. Transient Transfection Assays. Transient transfections were performed using the polyethylenimine (PEI) method as previously described $[7,28]$. PC12 cells grown in 24-well tissue culture plates were transfected with $1.0 \mu \mathrm{g}$ of wildtype promoter-luciferase reporter gene construct using $5 \mu \mathrm{L}$ of $1 \mathrm{X}$ polyethylenimine to transfect $1 \mu \mathrm{g}$ of plasmid with an incubation period of $3 \mathrm{~h}$. After transfection, the cells were washed with phosphate buffered saline (PBS, pH 7.4) and maintained in culture medium for $24 \mathrm{~h}$, followed by drug treatment.

2.7. Luciferase Assays. Cell culture medium was removed, the cells rinsed twice with PBS and then lysed with $100 \mu \mathrm{L}$ lysis buffer (1.25 mM Tris-phosphate, pH 7.8, 2 mM DTT, $2 \mathrm{mM}$ 1,2-diaminocyclohexane-N,N,N, $\mathrm{N}^{\prime}$-tetraacetic acid $10 \%$ Glycerol and 1\% Triton X-100) and subjection to a freeze-thaw cycle. Cell lysates were centrifuged at $3000 \mathrm{~g}$ for $10 \mathrm{~min}$, and $20 \mu \mathrm{L}$ of supernatant assayed for luciferase activity as previously described by Tai and Wong using a microplate luminometer (Fluostar Optima BMG Labtech Nepean, ON, Canada) [7]. Total protein in the lysates was determined by the method of Bradford (1976), and luciferase activity expressed as optical density units per $\mu \mathrm{g}$ of protein [29].

2.8. Data Analysis. All data are presented as the mean \pm SEM. Experiments were repeated at least three times and statistical significance between experimental and control groups was determined by one-way ANOVA followed by a posthoc comparison using the Student-Newman-Keuls for multiple comparisons test. Results were considered statistically significant with a $P<0.05$.

\section{Results}

3.1. Effect of $\mathrm{CoCl}_{2}$ and Hypoxia on Intracellular ROS and NO Levels. PC12 cells treated with $200 \mu \mathrm{M} \mathrm{CoCl}_{2}$ or exposed to $5 \%$ oxygen for $24 \mathrm{~h}$ increased intracellular ROS levels 2.3 -fold $(P<0.01)$ and 1.7 -fold $(P<0.05)$, respectively, compared to control (Figure 1(a)). Conversely, PC12 cells treated with $\mathrm{CoCl}_{2}$ or exposed to $5 \%$ oxygen for $24 \mathrm{~h}$ showed a significant decrease of $3 \mu \mathrm{M}(P<0.05)$ and $6 \mu \mathrm{M}(P<0.01)$ in intracellular NO levels, respectively, compared to control (Figure 1(b)).

3.2. Effect of NAC on $\mathrm{CoCl}_{2}$ Induced Gene Expression and on Intracellular ROS and NO Levels. $\mathrm{CoCl}_{2}$ treatment significantly increased PNMT intron-retaining and intronless mRNA levels by 3.0 -fold $(P<0.01)$ and $1.76(P<0.01)$ respectively, compared to untreated control. To assess whether mRNA induction of PNMT by $\mathrm{CoCl}_{2}$ could be abolished by antioxidant treatment, cells were pretreated with $5 \mathrm{mM} \mathrm{NAC}$ for $30 \mathrm{~min}$ prior to $\mathrm{CoCl}_{2}$ delivery (Figures 2(a), 2(b), and 2(c)). Cells pretreated with NAC prior to $\mathrm{CoCl}_{2}$ delivery showed decreased PNMT intronretaining and intronless mRNA levels by 2.0 -fold $(P<0.01)$ and 0.9 -fold $(P<0.01)$, respectively, compared to $\mathrm{CoCl}_{2}$ controls (Figures 2(b) and 2(c)).

To confirm the scavenging of ROS by NAC during $\mathrm{CoCl}_{2}$ stress, intracellular ROS levels were measured after $24 \mathrm{~h}$. NAC treatment significantly reduced basal levels of intracellular ROS by 0.5 -fold $(P<0.05)$ and significantly reduced levels of $\mathrm{CoCl}_{2}$-generated ROS by 1.8 -fold $(P<$ 0.001 ) compared to control (Figure 2(d)). Cells treated with $5 \mathrm{mM}$ NAC reduced basal NO levels by $15 \mu \mathrm{M}(P<0.001)$, while cells treated with $\mathrm{CoCl}_{2}$ alone significantly reduced NO levels by $3.4 \mu \mathrm{M}$ compared to control. Cells pretreated with NAC prior to $\mathrm{CoCl}_{2}$ treatment showed no significant change in NO levels compared to cells treated with $\mathrm{CoCl}_{2}$ alone (Figure 2(e)). 
TABLE 1: The following primer sets were used for PNMT and glyceraldehyde-3-phosphate dehydrogenase (GAPDH).

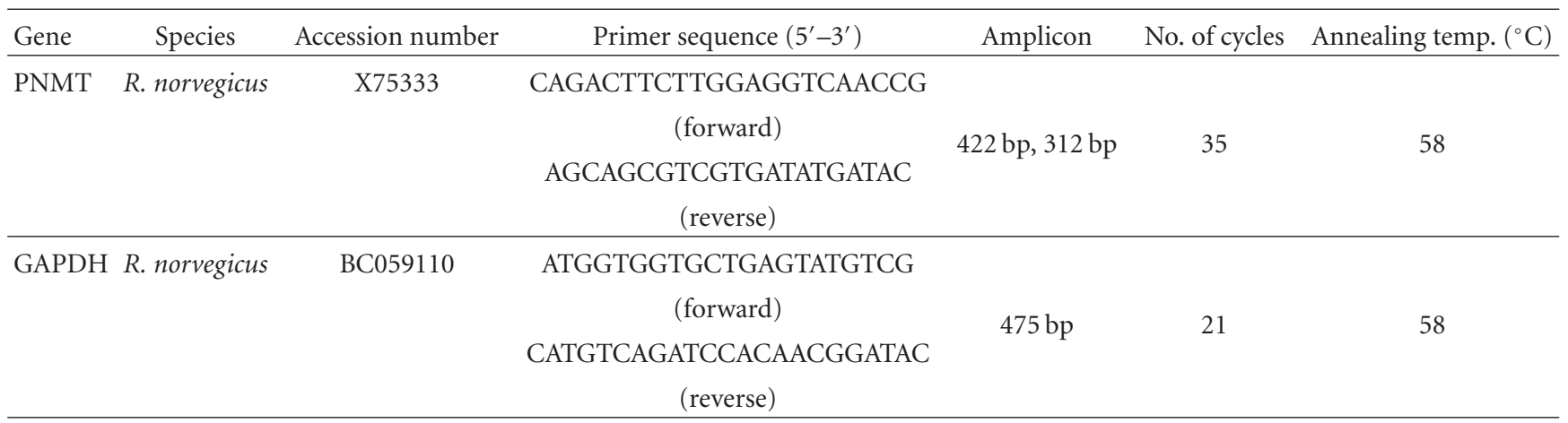

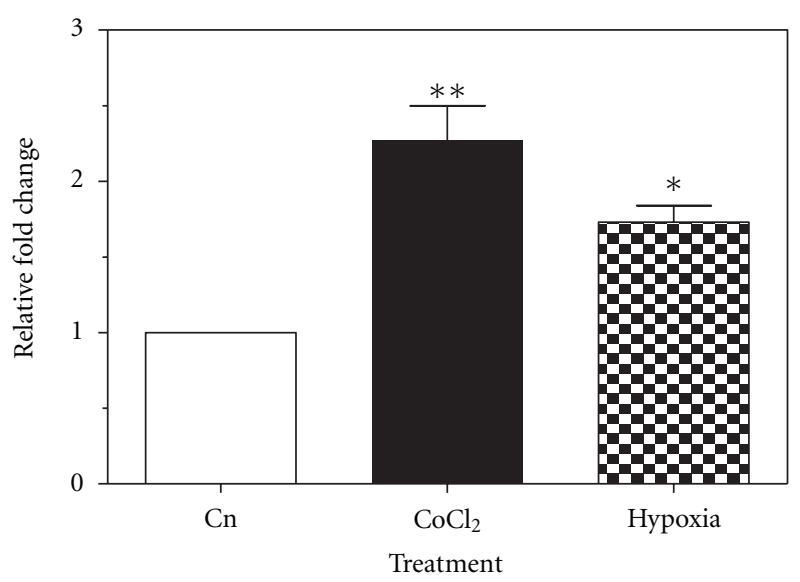

(a) Intracellular ROS levels

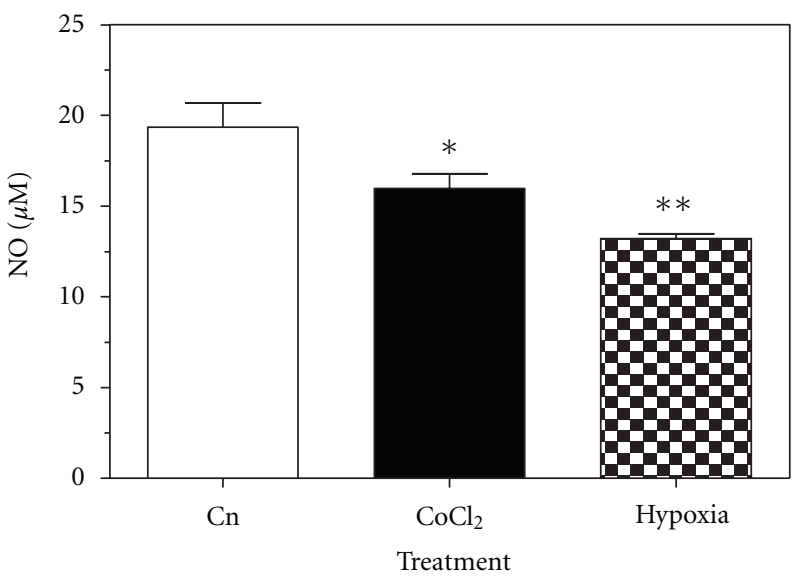

(b) NO concentration

FIGURE 1: Effect of $\mathrm{CoCl}_{2}$ and hypoxia exposure on free radicals. Levels of intracellular ROS (a) and extracellular NO (b) were measured in PC12 cells following $24 \mathrm{~h}$ exposure to either $200 \mu \mathrm{M} \mathrm{CoCl}_{2}$ or $5 \%$ oxygen at $37^{\circ} \mathrm{C}$. Data presented as relative fold change or $\mathrm{NO}$ concentration \pm SEM from a minimum of three independent experiments. Significance defined as ${ }^{*} P<0.05 ;{ }^{*} P<0.01$.

3.3. Effect of ROS on the Hormonal Regulation of the PNMT Gene. To determine whether the intracellular ROS generated by $\mathrm{CoCl}_{2}$ could potentiate the glucocorticoid activation of the PNMT gene, transient transfection assays and RT-PCR were performed on cells treated with $200 \mu \mathrm{M}$ of $\mathrm{CoCl}_{2}$, $1 \mu \mathrm{M}$ of dexamethasone and the combination of both drugs for $24 \mathrm{~h}$. Transient transfection assays with a PNMT promoter-luciferase reporter gene construct harbouring the proximal $-893 \mathrm{bp}$ (pGL3RP893), revealed activation of the PNMT promoter following dexamethasone treatment (2.9fold; $P<0.05), \mathrm{CoCl}_{2}$ treatment (3.7-fold, $\left.P<0.01\right)$, and the combination treatment (18.5-fold; $P<0.001)$ (Figure 3(a)). RT-PCR demonstrated increased expression of the intron-retaining splice variant of PNMT when treated with $\mathrm{CoCl}_{2}$ (3.0-fold; $\left.P<0.001\right)$ and decreased expression when treated in combination with dexamethasone (0.8-fold; $P<0.001$ ) (Figure 3(c)). Further, RT-PCR showed increased expression of the intronless splice variant of PNMT when treated with $\mathrm{CoCl}_{2}(2.7$-fold; $P<0.05)$ compared to control and decreased expression when treated in combination with dexamethasone (2.7-fold; $P<0.01)$, compared to treatment with dexamethasone alone $(3.5$-fold; $P<0.001)$ (Figure 3(d)).

3.4. Effect of ROS on the Neural Regulation of the PNMT Gene. To determine whether intracellular ROS generated via $\mathrm{CoCl}_{2}$ treatment could potentiate the cholinergic activation of the PNMT gene, transient transfection assays and RTPCR were performed on cells treated with $200 \mu \mathrm{M}$ of $\mathrm{CoCl}_{2}$, $10 \mu \mathrm{M}$ of forskolin and the combination of both drugs for $24 \mathrm{~h}$. Transient transfection assays with a PNMT promoterluciferase reporter gene construct harbouring the proximal $-893 \mathrm{bp}$ (pGL3RP893), revealed activation of the PNMT promoter following forskolin treatment $(2.4$-fold; $P<0.05)$, $\mathrm{CoCl}_{2}$ treatment $(3.7$-fold, $P<0.01)$, and the combination treatment (12.1-fold; $P<0.001$ ) (Figure 4(a)). Combination treatment of forskolin and $\mathrm{CoCl}_{2}$ showed a decrease in intron-retaining PNMT mRNA levels (1.0-fold, $P<0.001)$ compared to $\mathrm{CoCl}_{2}$ treatment alone (Figures 4(b) and 4(c)). RT-PCR for the PNMT intronless splice variant demonstrated increased expression when treated with forskolin (2.0-fold, $P<0.01$ ), compared to control (Figures 4(b) 


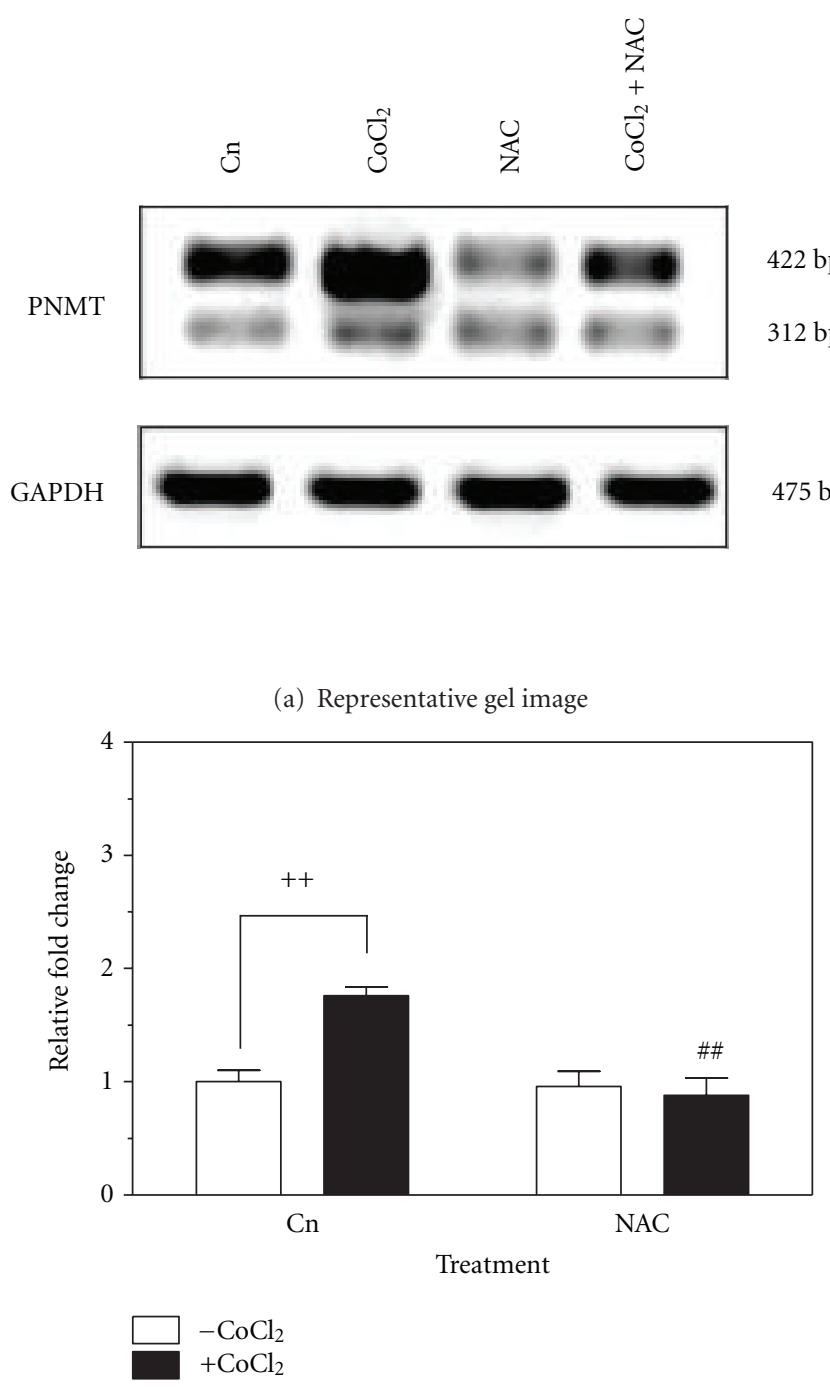

(c) PNMT intronless mRNA

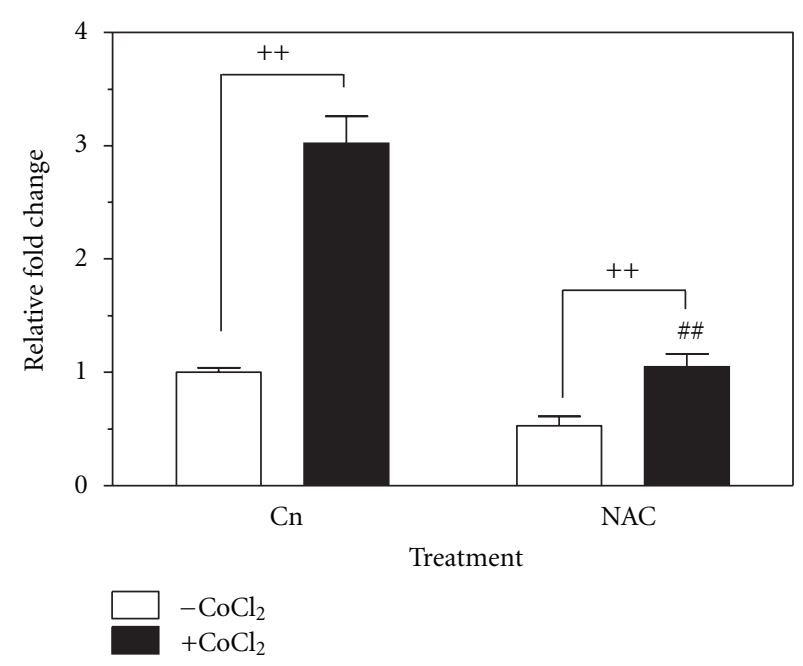

(b) PNMT intron-retaining mRNA

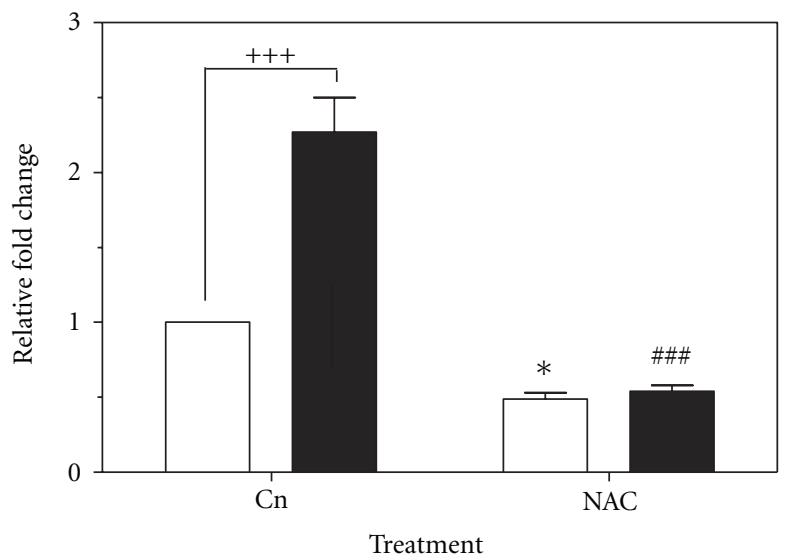

$\square-\mathrm{CoCl}_{2}$

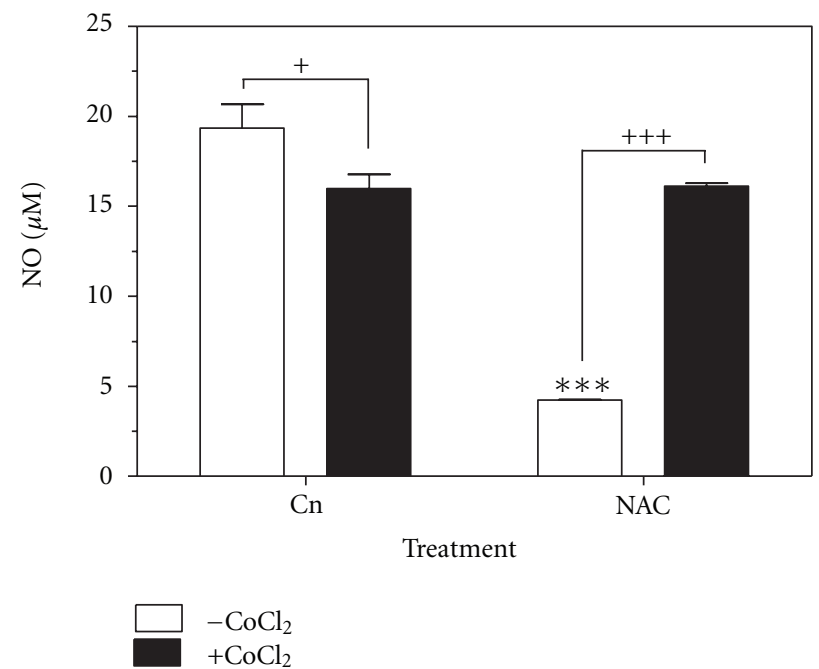

(e) NO concentration

Figure 2: Effect of NAC pretreatment on levels of PNMT mRNA, intracellular ROS, and extracellular NO in PC12 cells treated with $200 \mu \mathrm{M} \mathrm{CoCl} 2$ for $24 \mathrm{~h}$ at $37^{\circ} \mathrm{C}$. (a) Representative image $(n=3)$ of PNMT (intron-retaining and intronless splice variants) mRNA levels from semiquantitative RT-PCR. GAPDH mRNA was used as a housekeeping control. (b) PNMT intron-retaining mRNA and (c) intronless mRNA. Data is normalized to GAPDH control. (d) Intracellular ROS levels and (e) NO concentration after $24 \mathrm{~h}$. Data presented as relative fold change or NO concentration \pm SEM from a minimum of three independent experiments. Significance defined as ${ }^{* /+} P<0.05$; ${ }^{++/ \# \#} P<0.01 ;{ }^{* * * /+++/ \# \# \#} P<0.001$. 


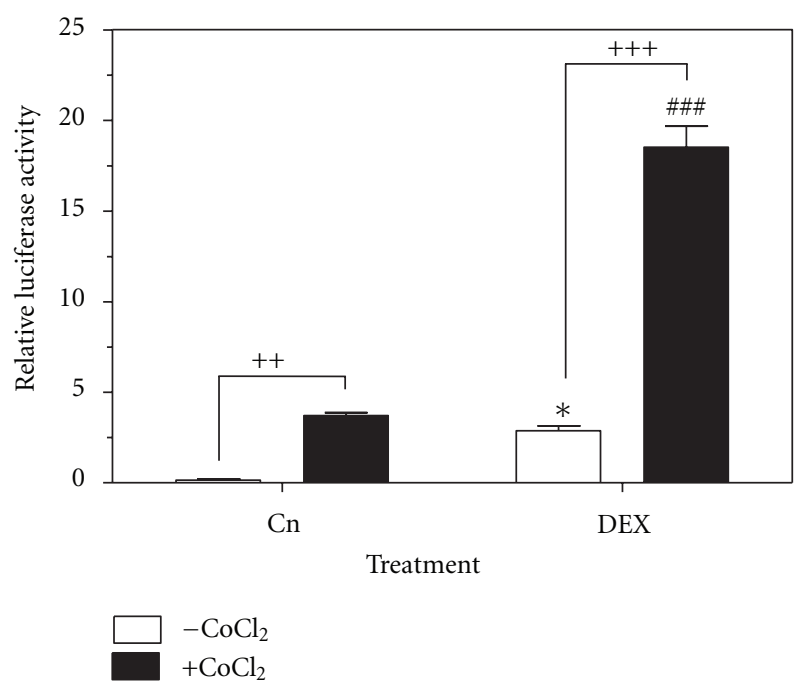

(a) Transfection

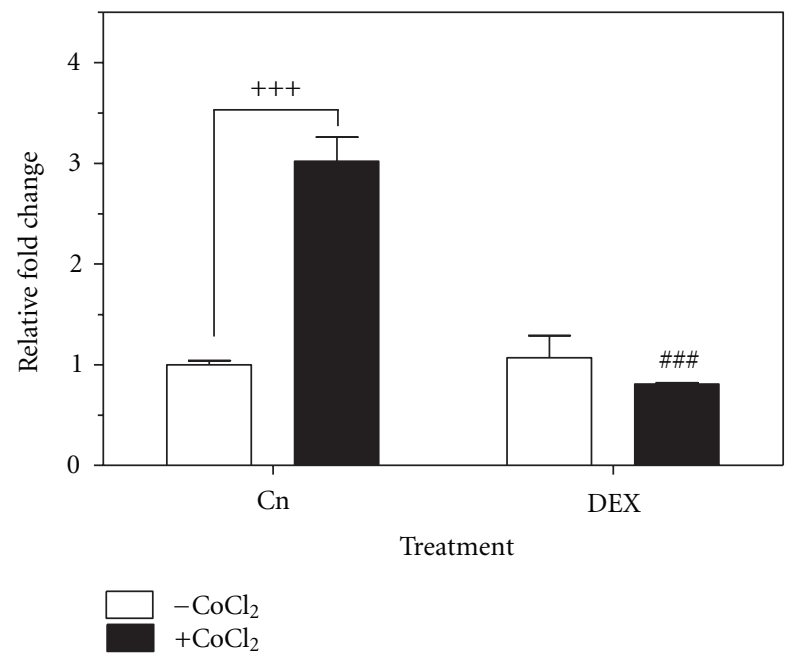

(c) PNMT intron-retaining mRNA

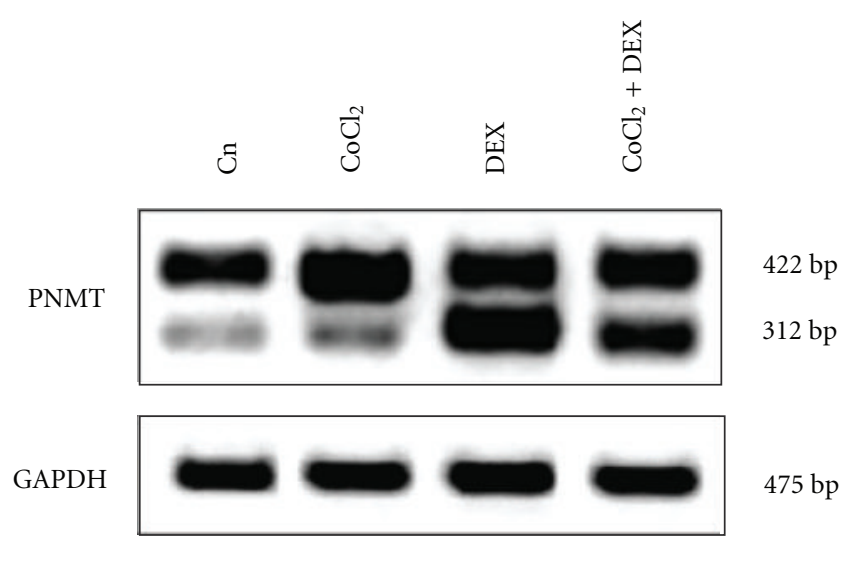

(b) Representative gel image

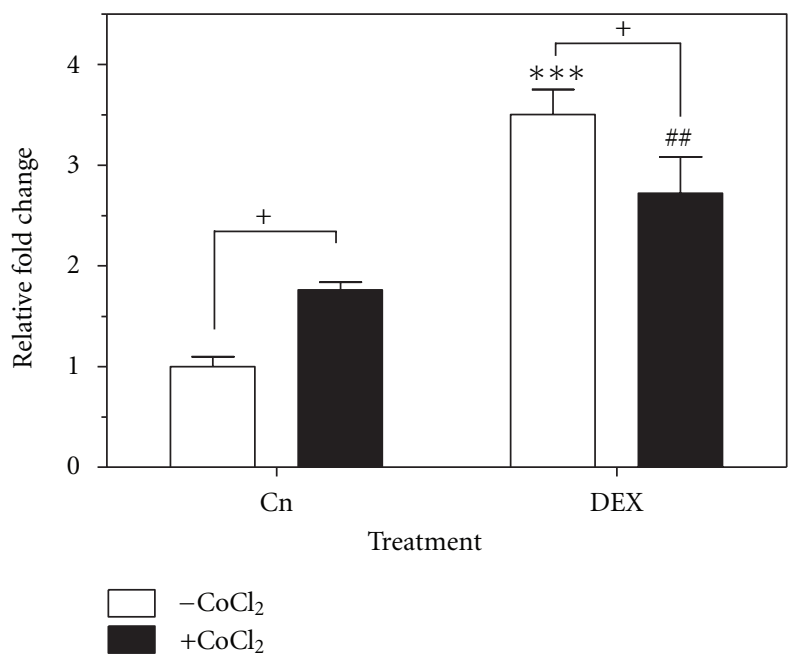

(d) PNMT intronless mRNA

FIGURE 3: Effect of ROS on the hormonal regulation of the PNMT gene. PC12 cells were treated with $200 \mu \mathrm{M} \mathrm{CoCl}_{2}, 1 \mu \mathrm{M}$ dexamethasone or the combination of $\mathrm{CoCl}_{2}$ and dexamethasone for $24 \mathrm{~h}$ at $37^{\circ} \mathrm{C}$. (a) Luciferase activity from cells transfected with the wild-type pGL3RP893 PNMT promoter luciferase reporter gene construct. (b) Representative image $(n=3)$ of PNMT (intron-retaining and intronless splice variants) mRNA levels from semiquantitative RT-PCR. GAPDH mRNA was used as a housekeeping control. (c) PNMT intron-retaining mRNA and (d) intronless mRNA. Data is normalized to GAPDH control. Data presented as relative fold change \pm SEM from a minimum of three independent experiments. Significance defined as ${ }^{* /+} P<0.05 ;^{++/ \# \#} P<0.01 ;^{* * * /+++/ \# \#} P<0.001$.

and 4(d)), however, showed no further increase when treated in combination with $\mathrm{CoCl}_{2}$.

\section{Discussion}

Epinephrine is found in the adrenal medulla, adrenergic neurons, the heart, the spleen, and the liver. It is involved in a variety of regulatory systems such as psychomotor activity, sleep, memory and the stress response [30]. In adrenergic cells, norepinephrine is $\mathrm{N}$-methylated by the enzyme phenylethanolamine $\mathrm{N}$-methyltransferase (PNMT) using S-adenosyl methionine as a co-substrate and a methyl donor to form epinephrine [12]. Understanding epinephrine production via its synthesizing enzyme PNMT is essential to elucidating its role as a neuroendocrine regulator in disease states [2]. Activation and regulatory mechanisms of the PNMT gene have been studied extensively in various systems. Recent studies demonstrate that PNMT is a stressresponsive enzyme with stressor-specific responses [31, 32]. Hypoxic stress is one of the many stressors that can stimulate the PNMT gene [17]. Tai et al., 2009, have previously demonstrated that hypoxia and $\mathrm{CoCl}_{2}$ stimulate the hypoxia inducible factor (HIF) $1 \alpha$ in PC12 cells to activate the PNMT promoter and PNMT [13]. In adrenomedullary chromaffin cells, trans-synaptic regulation of PNMT is mediated via neurotransmitter release from the splanchnic nerve, which 


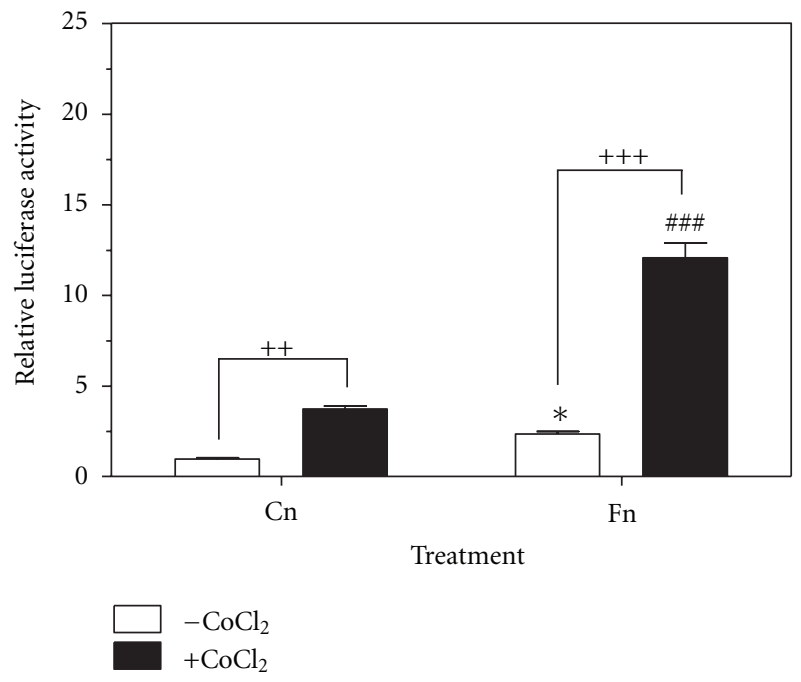

(a) Transfection

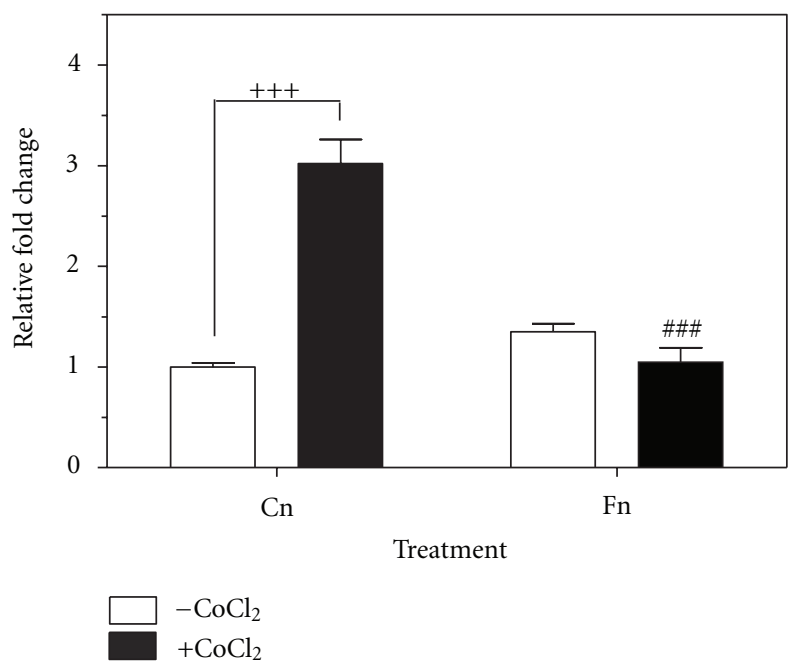

(c) PNMT intron-retaining mRNA

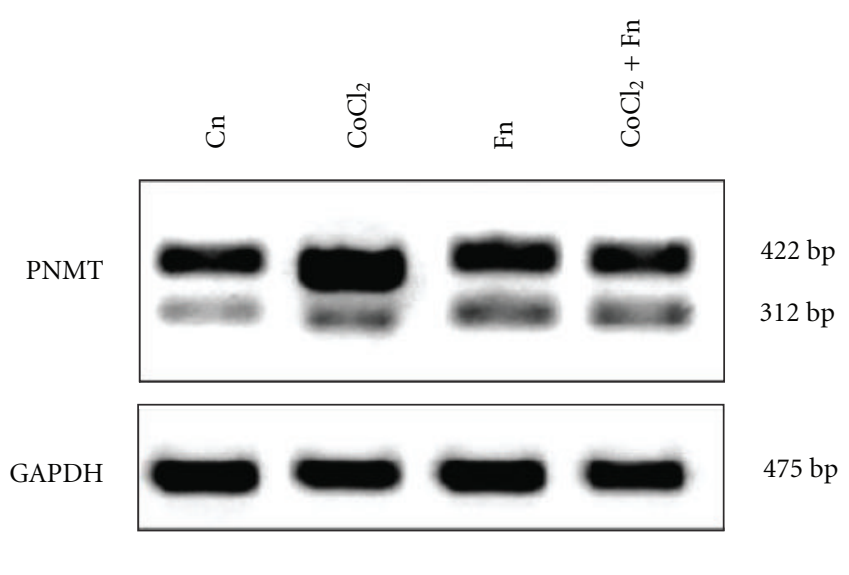

(b) Representative gel image

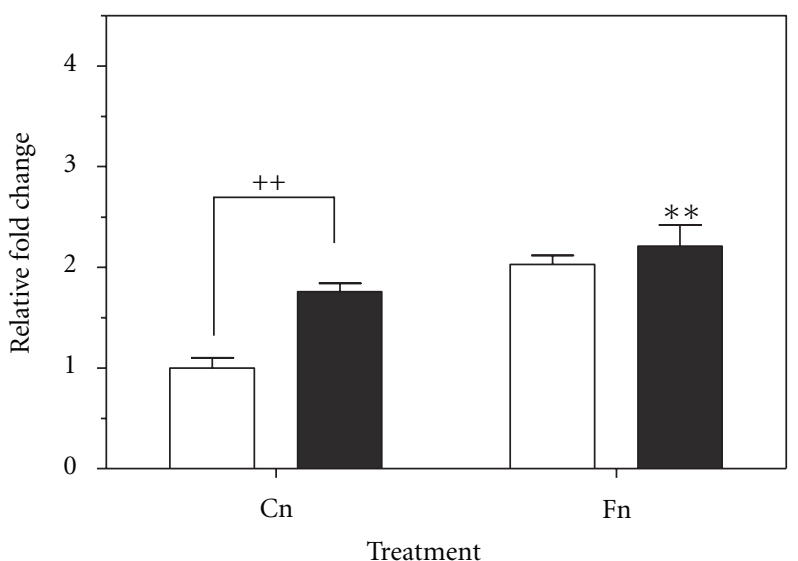

$-\mathrm{CoCl}_{2}$

$+\mathrm{CoCl}_{2}$

(d) PNMT intronless mRNA

FIGURE 4: Effect of ROS on the neural regulation of the PNMT gene. PC12 cells were treated with $200 \mu \mathrm{M} \mathrm{CoCl} 2,10 \mu \mathrm{M}$ forskolin or the combination of $\mathrm{CoCl}_{2}$ and forskolin for $24 \mathrm{~h}$ at $37^{\circ} \mathrm{C}$. (a) Luciferase activity from cells transfected with the wild-type pGL3RP893 PNMT promoter luciferase reporter gene construct. (b) Representative image $(n=3)$ of PNMT (intron-retaining and intronless splice variants) mRNA levels from semi-quantitative RT-PCR. GAPDH mRNA was used as a housekeeping control. (c) PNMT intron-retaining mRNA and (d) intronless mRNA. Data is normalized to GAPDH control. Data presented as relative fold change \pm SEM from a minimum of three independent experiments. Significance defined as ${ }^{*} P<0.05 ;{ }^{* * /++} P<0.01$; $^{+++/ \# \# \#} P<0.001$.

leads to the activation of the PNMT gene [9]. Additionally, the biosynthesis of epinephrine in the adrenal medulla is dependent on high concentrations of glucocorticoids [33]. Glucocorticoids control PNMT post-translationally by indirectly preventing the degradation of the PNMT enzyme and by regulating the expression of PNMT mRNA [2]. The objectives of this study were to examine and elucidate the roles of reactive oxygen species (ROS), generated by the hypoxia mimetic agent $\mathrm{CoCl}_{2}$ on the hormonal and neural regulation of the PNMT gene.

ROS exert critical intracellular functions, including signal transduction, gene transcription, and the regulation of guanylate cyclase activity in cells [34]. Intracellular levels of ROS have been demonstrated to augment during stress, which includes hypoxia [35]. The ROS nitric oxide (NO) is recognized as an essential intracellular messenger in the central and peripheral nervous systems. Previous studies have shown that NO leads to long-term upregulation of PNMT and other catecholamine biosynthetic enzymes, and that this is mediated by the cyclic GMP-dependent signaling pathway [36]. As such, we examined intracellular levels of ROS and extracellular levels of NO in PC12 cells exposed to hypoxia or treated with $\mathrm{CoCl}_{2}$. Our findings confirm that hypoxia and $\mathrm{CoCl}_{2}$ both increase intracellular levels of ROS and show that both treatments result in decreased extracellular NO. This demonstrates that $\mathrm{CoCl}_{2}$ acts as a 
hypoxia mimetic agent by increasing ROS in addition to the stabilization of HIF $1 \alpha$ and is suggestive that $\mathrm{NO}$ is not involved in the induction of PNMT by $\mathrm{CoCl}_{2}$.

Treatment of cells having elevated levels of ROS with known antioxidants, including $\mathrm{N}$-acetylcysteine (NAC) and polyphenols, has demonstrated the ability to prevent ROSinduced responses [22]. Our findings confirm the upregulation of both the intronless and intron-retaining transcripts of the PNMT gene via ROS [31]. Furthermore, decreased intracellular levels of ROS and subsequent inhibition of PNMT transcription were observed when cells were treated jointly with $\mathrm{CoCl}_{2}$ and NAC. Since previous studies have demonstrated that $\mathrm{CoCl}_{2}$ mimics hypoxia by causing the stabilization of HIF proteins, our findings further confirm that NAC can effectively abolish the HIF1 $\alpha$ stabilization by $\mathrm{CoCl}_{2}$, subsequently inhibiting the transcription of PNMT $[37,38]$. In an effort to further elucidate the role of $\mathrm{CoCl}_{2}$ generated ROS on PNMT activation and transcription, we examined the combined effects of $\mathrm{CoCl}_{2}$ treatment with dexamethasone or forskolin, known hormonal and neural activators of the PNMT promoter. Similar to previous studies, we have demonstrated that both dexamethasone and forskolin increase the expression of the intronless splice variant of the PNMT gene $[6,9]$.

Glucocorticoids are steroid hormones released from the adrenal cortex and are the principle effectors in the stress response [39]. Glucocorticoid sensitivity has been reported for PNMT promoter activity in rat and bovine, and at least one putative glucocorticoid response element (GRE) has been identified for every species-specific PNMT gene [40]. The current study shows that PC12 cells transfected with the full-length promoter and treated with both $\mathrm{CoCl}_{2}$ and dexamethasone results in a synergistic effect and further drives transcription of the PNMT gene greater than the treatment with either drug alone. This response may be attributed to a previously reported redox mechanism in which $\mathrm{CoCl}_{2}$ increases stabilized glucocorticoid receptor (GR) protein within the cell [41]. Additionally, individual studies have identified an active $-282 \mathrm{bp}$ hypoxia response element (HRE) and $-533,-759$ and $-773 \mathrm{bp}$ GREs on the PNMT promoter $[6,13]$. We hypothesize, that it is the combined stimulation of these elements that are giving rise to the observed synergistic activation of the PNMT promoter. Moreover, increased protein levels of the transcription factors, early growth response factor 1 (Egr-1) and specificity protein 1 (Sp1) by HIF1 $\alpha$, may further drive the PNMT promoter, giving rise to increased levels of cytoplasmic PNMT protein $[13,19]$. Although, synergistic effect at the transcriptional level is not observed, a shift from the intronretaining variant of PNMT to the intronless variant is present, suggesting further post-transcriptional regulation by $\mathrm{CoCl}_{2}$ and dexamethasone.

Previous studies have demonstrated that forskolin treatment may lead to neural activation of the rat PNMT promoter via the protein kinase A (PKA) and protein kinase $\mathrm{C}$ (PKC) pathways, subsequently leading to increased nuclear protein levels of Egr-1 and Sp1 and increased cytoplasmic PNMT protein $[7,42,43]$. Our findings reveal that PC12 cells transfected with the full-length promoter and treated with both $\mathrm{CoCl}_{2}$ and forskolin results in a synergistic effect and further drives transcription of the PNMT gene greater than treatment with either drug alone. We attribute this response to the combination of multiple factors, mainly stabilized GR protein by $\mathrm{CoCl}_{2}$, increased activation of the HRE by HIF $1 \alpha$, and increased Egr- 1 and Sp 1 activation of the PNMT promoter. While we can currently only hypothesize on the exact mechanisms responsible for the synergistic activation of the PNMT promoter, future overexpression and knockdown experiments on key regulatory factors will permit for a better understanding of PNMT regulation. Similar to combination treatments with dexamethasone, we show a shift from the intron-retaining variant of PNMT to the intronless variant when treated with $\mathrm{CoCl}_{2}$ and forskolin. These findings suggest post-transcriptional regulation of PNMT by these two drugs.

In summary, previous studies have elucidated and identified factors involved in the activation of the PNMT promoter via the hormonal and neural pathways. Additionally, the activation and synthesis of PNMT protein has been shown through the upregulation of HIF $1 \alpha$ by the hypoxia mimetic agent $\mathrm{CoCl}_{2}$. For the first time, our findings show that hypoxia has synergistic effects on the activation of the PNMT promoter when combined with activation by dexamethasone or forskolin. Furthermore, this study shows that NO is likely not involved in the ROS-mediated transcription of the PNMT gene and that antioxidant treatment in combination with $\mathrm{CoCl}_{2}$ can abolish the ROS-mediated upregulation of the PNMT gene.

\section{Acknowledgments}

This study was funded by the Northern Ontario School of Medicine and the Natural Sciences and Engineering Research Council of Canada. Technical assistance in the measurements of intracellular ROS was provided by Matthew Piche.

\section{References}

[1] D. L. Wong, B. Siddall, and W. Wang, "Hormonal control of rat adrenal phenylethanolamine $\mathrm{N}$-methyltransferase: enzyme activity, the final critical pathway," Neuropsychopharmacology, vol. 13, no. 3, pp. 223-234, 1995.

[2] D. L. Wong, "Epinephrine biosynthesis: hormonal and neural control during stress," Cellular and Molecular Neurobiology, vol. 26, no. 4-6, pp. 891-900, 2006.

[3] R. Kvetnansky, "Stressor specificity and effect of prior experience on catecholamine biosynthetic enzyme phenylethanolamine N-methyltransferase," Annals of the New York Academy of Sciences, vol. 1032, pp. 117-129, 2004.

[4] R. Kvetnansky, E. L. Sabban, and M. Palkovits, "Catecholaminergic systems in stress: structural and molecular genetic approaches," Physiological Reviews, vol. 89, no. 2, pp. 535-606, 2009.

[5] D. L. Wong, "Why is the adrenal adrenergic?" Endocrine Pathology, vol. 14, no. 1, pp. 25-36, 2003.

[6] T. C. Tai, R. Claycomb, S. Her, A. K. Bloom, and D. L. Wong, "Glucocorticoid responsiveness of the rat phenylethanolamine 
N-methyltransferase gene," Molecular Pharmacology, vol. 61, no. 6, pp. 1385-1392, 2002.

[7] T. C. Tai and D. L. Wong, "Protein kinase A and protein kinase $\mathrm{C}$ signaling pathway interaction in phenylethanolamine $\mathrm{N}$ methyltransferase gene regulation," Journal of Neurochemistry, vol. 85, no. 3, pp. 816-829, 2003.

[8] E. J. Whalen, T. B. Saurer, A. K. Johnson, and S. J. Lewis, "Intracellular cGMP may promote $\mathrm{Ca} 2+$-dependent and $\mathrm{Ca} 2+-$ independent release of catecholamines from sympathetic nerve terminals," Vascular Pharmacology, vol. 45, no. 2, pp. 102-111, 2006.

[9] M. Jaramillo and M. Olivier, "Hydrogen peroxide induces murine macrophage chemokine gene transcription via extracellular signal-regulated kinase-and cyclic adenosine 5'monophosphate (cAMP)-dependent pathways: involvement of NF- $\kappa \mathrm{B}$, activator protein 1 , and cAMP response element binding protein," Journal of Immunology, vol. 169, no. 12, pp. 7026-7038, 2002.

[10] H. J. Choi, S. Y. Park, and O. Hwang, "Differential involvement of PKA and PKC in regulation of catecholamine enzyme genes by PACAP," Peptides, vol. 20, no. 7, pp. 817-822, 1999.

[11] N. Yukimasa, K. Isobe, H. Nagai, Y. Takuwa, and T. Nakai, "Successive occupancy by immediate early transcriptional factors of the tyrosine hydroxylase gene TRE and CRE sites in PACAP-stimulated PC12 pheochromocytoma cells," Neuropeptides, vol. 33, no. 6, pp. 475-482, 1999.

[12] D. L. Wong, L. J. Anderson, and T. C. Tai, "Cholinergic and peptidergic regulation of phenylethanolamine $\mathrm{N}$ methyltransferase gene expression," Annals of the New York Academy of Sciences, vol. 971, pp. 19-26, 2002.

[13] T. C. Tai, D. C. Wong-Faull, R. Claycomb, and D. L. Wong, "Hypoxic stress-induced changes in adrenergic function: role of HIF1 $\alpha$," Journal of Neurochemistry, vol. 109, no. 2, pp. 513524, 2009.

[14] S. Kaluz, M. Kaluzová, and E. J. Stanbridge, "Regulation of gene expression by hypoxia: integration of the HIF-transduced hypoxic signal at the hypoxia-responsive element," Clinica Chimica Acta, vol. 395, no. 1-2, pp. 6-13, 2008.

[15] N. S. Kenneth and S. Rocha, "Regulation of gene expression by hypoxia," Biochemical Journal, vol. 414, no. 1, pp. 19-29, 2008.

[16] M. F. Czyzyk-Krzeska, B. A. Furnari, E. E. Lawson, and D. E. Millhorn, "Hypoxia increases rate of transcription and stability of tyrosine hydroxylase mRNA in pheochromocytoma (PC12) cells," Journal of Biological Chemistry, vol. 269, no. 1, pp. 760-764, 1994.

[17] M. J. Evinger, S. Cikos, V. Nwafor-Anene, J. F. Powers, and A. S. Tischler, "Hypoxia activates multiple transcriptional pathways in mouse pheochromocytoma cells," Annals of the New York Academy of Sciences, vol. 971, pp. 61-65, 2002.

[18] D. L. Wong, T. C. Tai, D. C. Wong-Faull, R. Claycomb, and R. Kvetnansky, "Genetic mechanisms for adrenergic control during stress," Annals of the New York Academy of Sciences, vol. 1018, pp. 387-397, 2004.

[19] D. L. Wong, T. C. Tai, D. C. Wong-Faull et al., "Stress and adrenergic function: HIF $1 \alpha$, a potential regulatory switch," Cellular and Molecular Neurobiology, pp. 1-7, 2010.

[20] R. Visconti and D. Grieco, "New insights on oxidative stress in cancer," Current Opinion in Drug Discovery and Development, vol. 12, no. 2, pp. 240-245, 2009.

[21] R. O. Poyton, K. A. Ball, and P. R. Castello, "Mitochondrial generation of free radicals and hypoxic signaling," Trends in Endocrinology and Metabolism, vol. 20, no. 7, pp. 332-340, 2009.
[22] J. A. G. Crispo, D. R. Ansell, M. Piche et al., "Protective effects of polyphenolic compounds on oxidative stressinduced cytotoxicity in PC12 cells," Canadian Journal of Physiology and Pharmacology, vol. 88, no. 4, pp. 429-438, 2010.

[23] W. Zou, M. Yan, W. Xu et al., "Cobalt chloride induces PC12 cells apoptosis through reactive oxygen species and accompanied by AP-1 activation," Journal of Neuroscience Research, vol. 64, no. 6, pp. 646-653, 2001.

[24] G. Wang, T. K. Hazra, S. Mitra, H. M. Lee, and E. W. Englander, "Mitochondrial DNA damage and a hypoxic response are induced by $\mathrm{CoCl} 2$ in rat neuronal PC12 cells," Nucleic Acids Research, vol. 28, no. 10, pp. 2135-2140, 2000.

[25] U. A. Leuenberger, D. Johnson, J. Loomis, K. S. Gray, and D. A. MacLean, "Venous but not skeletal muscle interstitial nitric oxide is increased during hypobaric hypoxia," European journal of applied physiology, vol. 102, no. 4, pp. 457-461, 2008.

[26] S. N. Ebert, S. L. Balt, J. P. B. Hunter, A. Gashler, V. Sukhatme, and D. L. Wong, "Egr-1 activation of rat adrenal phenylethanolamine N-methyltransferase gene," Journal of Biological Chemistry, vol. 269, no. 33, pp. 20885-20898, 1994.

[27] S. Her, R. A. Bell, A. K. Bloom, B. J. Siddall, and D. L. Wong, "Phenylethanolamine N-methyltransferase gene expression. SP1 and MAZ potential for tissue-specific expression," Journal of Biological Chemistry, vol. 274, no. 13, pp. 8698-8707, 1999.

[28] O. Boussif, F. LezoualC'H, M. A. Zanta et al., "A versatile vector for gene and oligonucleotide transfer into cells in culture and in vivo: polyethylenimine," Proceedings of the National Academy of Sciences of the United States of America, vol. 92, no. 16, pp. 7297-7301, 1995.

[29] M. M. Bradford, "A rapid and sensitive method for the quantitation of microgram quantities of protein utilizing the principle of protein dye binding," Analytical Biochemistry, vol. 72, no. 1-2, pp. 248-254, 1976.

[30] J. Bergquist, A. Ciubisz, A. Kaczor, and J. Silberring, "Catecholamines and methods for their identification and quantitation in biological tissues and fluids," Journal of Neuroscience Methods, vol. 113, no. 1, pp. 1-13, 2002.

[31] T. C. Tai, D. C. Wong-Faull, R. Claycomb, and D. L. Wong, "Hypoxia and adrenergic function: molecular mechanisms related to Egr-1 and Sp1 activation," Brain Research, vol. 1353, no. C, pp. 14-27, 2010.

[32] S. N. Ebert, S. E. Lindley, T. G. Bengoechea, D. Bain, and D. L. Wong, "Adrenergic differentiation potential in PC12 cells: influence of sodium butyrate and dexamethasone," Molecular Brain Research, vol. 47, no. 1-2, pp. 24-30, 1997.

[33] M. Ehrhart-Bornstein and S. R. Bornstein, "Cross-talk between adrenal medulla and adrenal cortex in stress," Annals of the New York Academy of Sciences, vol. 1148, pp. 112-117, 2008.

[34] M. Zheng and G. Storz, "Redox sensing by prokaryotic transcription factors," Biochemical Pharmacology, vol. 59, no. 1, pp. 1-6, 2000.

[35] N. R. Prabhakar, G. K. Kumar, and J. Nanduri, "Intermittent hypoxia augments acute hypoxic sensing via HIF-mediated ROS," Respiratory Physiology \& Neurobiology, vol. 174, pp. 230-234, 2010.

[36] D. Kim, H. J. Choi, S. W. Kim, S. W. Cho, and O. Hwang, "Upregulation of catecholamine biosynthetic enzymes by nitric oxide," Journal of Neuroscience Research, vol. 72, no. 1, pp. 98-104, 2003.

[37] H. H. Kim, S. E. Lee, W. J. Chung et al., "Stabilization of hypoxia-inducible factor- $1 \alpha$ is involved in the hypoxic stimuliinduced expression of vascular endothelial growth factor in osteoblastic cells," Cytokine, vol. 17, no. 1, pp. 14-27, 2002. 
[38] Y. Yuan, G. Hilliard, T. Ferguson, and D. E. Millhorn, "Cobalt inhibits the interaction between hypoxia-inducible factor- $\alpha$ and von Hippel-Lindau protein by direct binding to hypoxiainducible factor- $\alpha$," Journal of Biological Chemistry, vol. 278, no. 18, pp. 15911-15916, 2003.

[39] J. M. You, S. J. Yun, K. N. Nam, C. Kang, R. Won, and E. H. Lee, "Mechanism of glucocorticoid-induced oxidative stress in rat hippocampal slice cultures," Canadian Journal of Physiology and Pharmacology, vol. 87, no. 6, pp. 440-447, 2009.

[40] K. Kepp, P. Juhanson, V. Kozich, M. Ots, M. Viigimaa, and M. Laan, "Resequencing PNMT in European hypertensive and normotensive individuals: no common susceptibility variants for hypertension and purifying selection on intron 1," $B M C$ Medical Genetics, vol. 8, article no. 47, 2007.

[41] H. Kitagawa, I. Yamaoka, C. Akimoto et al., "A reduction state potentiates the glucocorticoid response through receptor protein stabilization," Genes to Cells, vol. 12, no. 11, pp. 12811287, 2007.

[42] T. C. Tai, K. Morita, and D. L. Wong, "Role of Egr1 in cAMP-dependent protein kinase regulation of the phenylethanolamine N-methyltransferase gene," Journal of Neurochemistry, vol. 76, no. 6, pp. 1851-1859, 2001.

[43] K. Morita, S. N. Ebert, and D. L. Wong, "Role of transcription factor Egr-1 in phorbol ester-induced phenylethanolamine N-methyltransferase gene expression," Journal of Biological Chemistry, vol. 270, no. 19, pp. 11161-11167, 1995. 


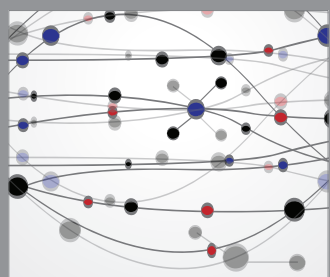

The Scientific World Journal
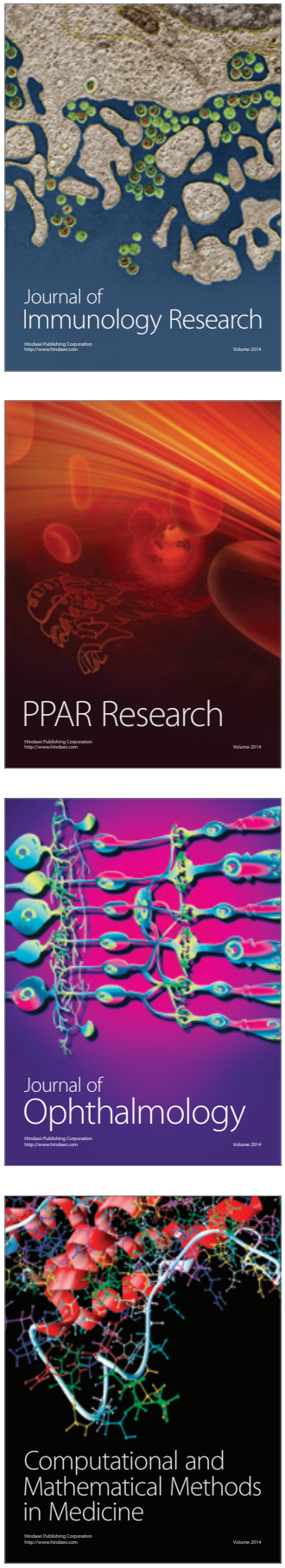

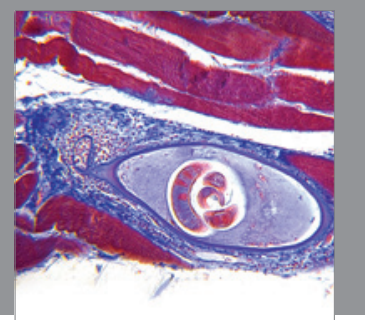

Gastroenterology

Research and Practice
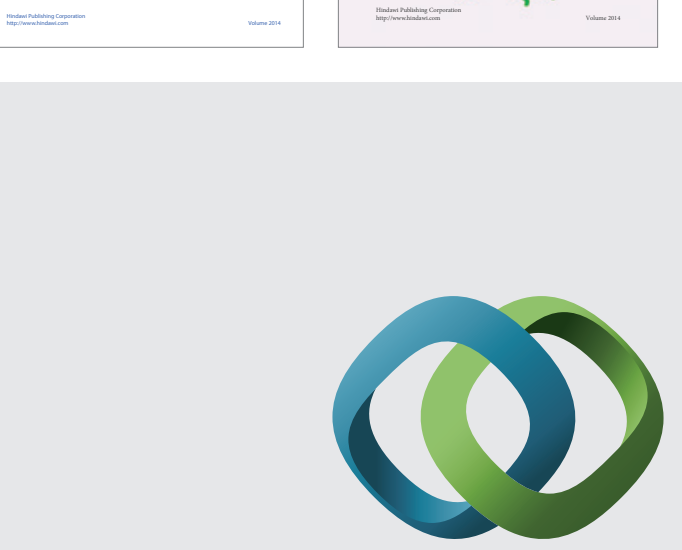

\section{Hindawi}

Submit your manuscripts at

http://www.hindawi.com
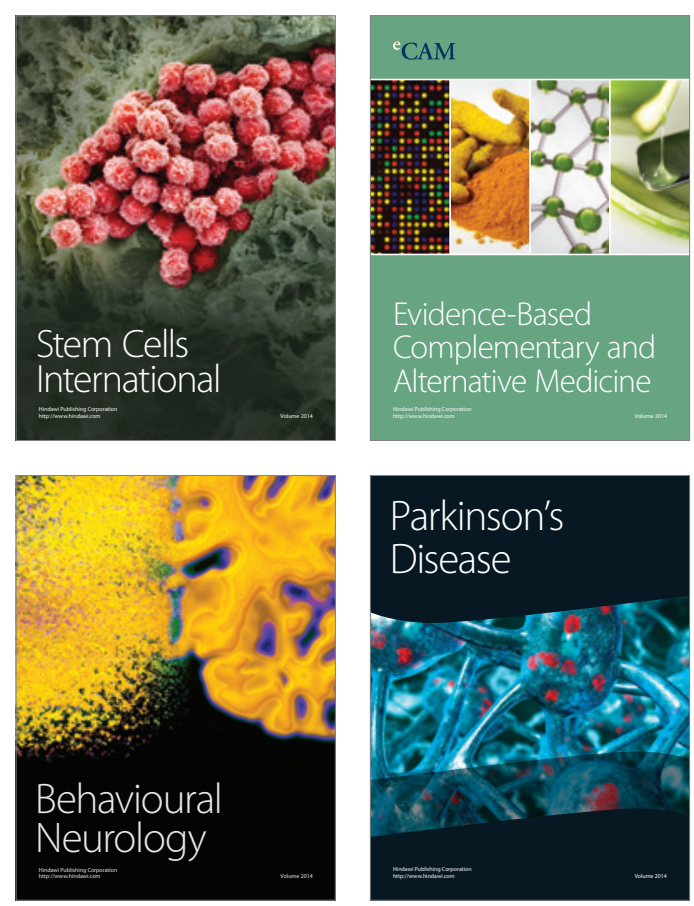

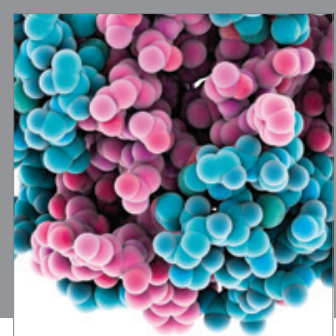

Journal of
Diabetes Research

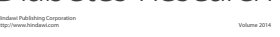

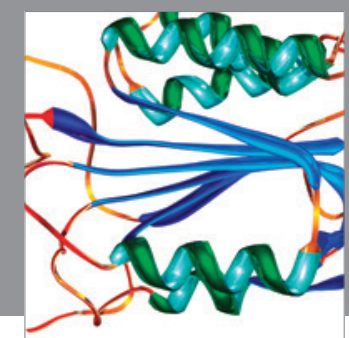

Disease Markers
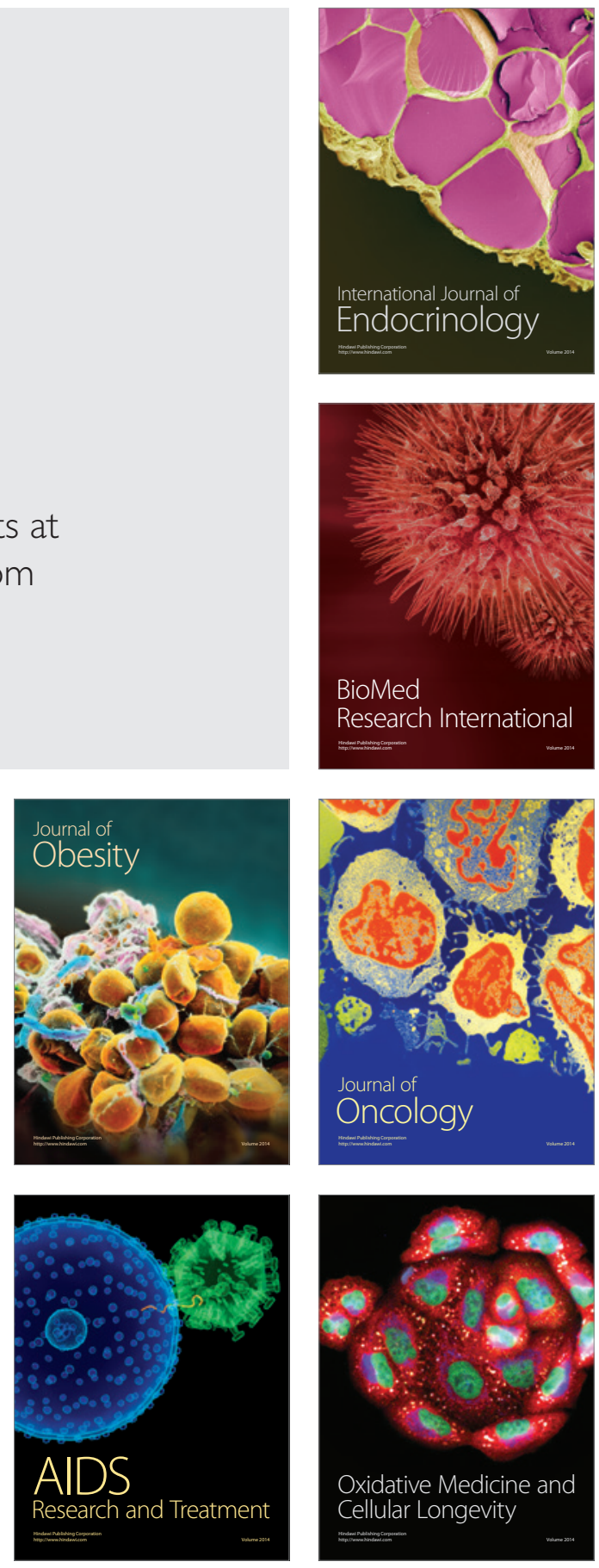